Ю.М. МОТУЗКА

Київський національний торговельно-економічний університет

\title{
ЗАСВОЮВАНІСТЬ БІЛКІВ ПРОДУКТІВ ДЛЯ ЕНТЕРАЛЬНОГО ХАРЧУВАННЯ
}

Ю.Н. МОТУЗКА

Киевский национальный торгово-экономический университет

\section{УСВОЯЕМОСТЬ БЕЛКОВ ПРОДУКТОВ ДЛЯ ЭНТЕРАЛЬНОГО ПИТАНИЯ}

I. MOTUZKA

Kyiv National University of Trade and Economics

\section{ASSIMILABILITY PROTEINS OF PRODUCTS FOR ENTERAL NUTRITION}

\section{https://doi.org/10.36910/6775-2310-5283-2018-11-04}

Мета. Дослідження засвоюваності білків продуктів для ентерального харчування системою ферментів шлунково-кишкового тракту для визначення їх біологічної повночінності.

Методика. Дослідження проводили згідно вимог ДСТУ 7617:2014 “Продукти харчові. Метод визначення засвоюваності білка" та методики Покровського-Сртанова. Суть методу полягає у дослідженні атакуємості білків in vitro комплексом протеолітичних ферментів - пепсином та трипсином.

Результати. Встановлено, щзо продукти для ентерального харчування легко піддаються гідролізу. У всіх досліджуваних продуктах залежності мають подібну тенденцію - процес як в пепсиновій, так $і$ в трипсиновій стадіях найбільш стрімко проходить за першу годину та за ией час утворюється найбільша концентрація продуктів розщеплення. Після сповільнення протягом другої години процесу гідроліз пепсинової стадії знову прискорюється на третій годині. Це пояснюється наявністю у досліджуваних продуктах рослинних екстрактів, які переважно характеризуються повільним протіканням гідролізу. Згідно класифікаиії Покровського А.А. продукти можна віднести до 1 групи харчових продуктів, яким притаманний швидкий темп перетравлюваності білка. При зберіганні продуктів для ентерального харчування амінокислоти можуть вступати в перехресні реакиії з іншими компонентами продуктів. Внаслідок даного процесу відбувається «блокування» незамінних амінокислот, особливо лізину, метіоніну та цистину. Це може спричинити зниження засвоєння білка організмом людини. Дослідження атакуємості білків продуктів in vitro протягом передбачуваного терміну зберігання засвідчили, щзо перетравлюваність білків у зразках знизилась на 1,8-3,5 \%. Зміна иієї характеристики проходить за рахунок зменшення доступного лізину у продуктах.

Наукова новизна. Встановлено закономірності засвоюваності білків продуктів для ентерального харчування системою ферментів илунково-кишкового тракту в процесі їх зберігання. 
Практична значимість. Проведені дослідження щзодо перетравлюваності білків підтвердили високу біологічну иінність продуктів для ентерального харчування. Це дозволяс рекомендувати включення продуктів у харчування хворих та травмованих осіб.

Ключові слова: засвоюваність, біологічна цінність, фермент, якість, перетравлюваність, продукт для ентерального харчування, зберігання.

\section{Постановка проблеми у загальному вигляді та її зв'язок 3 важливими} науковими та практичними завданнями. Якість продуктів для ентерального харчування визначається їх біологічною цінністю [1]. Перетравлюваність білків у шлунково-кишковому тракті лімітує засвоювання амінокислот організмом людини. Частково гідролізовані білки, що надходять до тонкого кишечника, та знаходячись там обмежений час, повинні швидко гідролізуватися до амінокислот та засвоїтися: потрапляння амінокислот до товстого кишечника рівноцінне їх втраті для організму. Одним із основних показників метаболічної адекватності білкової складової рецептур продуктів $\epsilon$ засвоюваність білка [2]. Тому біологічна цінність продукту визначається ступенем i швидкістю перетравлювання протеазами шлунково-кишкового тракту, засвоюванням амінокислот та подальшою утилізацією на пластичні потреби організму. Ефективність гідролізу білків продуктів залежить від амінокислотного складу, конформації молекул, умов технологічного оброблення продуктів [3]. Враховуючи функціональну направленість продуктів, важливим вбачається дослідження перетравлюваності їх білкової складової ферментами шлунково-кишкового тракту.

Аналіз останніх досліджень, у яких започатковано вирішення проблеми. Дослідженню біологічної цінності харчових продуктів протеолітичними ферментами присвячені роботи Покровського А.А., Ліпатова M.M., Чернова С.В., Рудакової Т.В. та ін. [4-7]. В наукових працях представлені результати дослідження біологічної цінності продуктів біологічними, хімічними та ферментативними методами. Зокрема, для визначення ферментативним методом біологічної цінності білка Покровським-Сртановим розроблено класичний прилад для гідролізу білків, а Ліпатовим здійснено його удосконалення. Рудаковою Т.В. проведено дослідження біологічної цінності продуктів для дитячого харчування за допомогою ферментативного методу та модифіковано конструкцію приладу для гідролізу білків [7]. Однак, насьогодні відсутні дослідження щодо оцінки засвоюваності білків продуктів для ентерального харчування, що, враховуючи багатокомпонентність їх складу та цільовий контингент споживачів, $\epsilon$ важливими в оцінці їх біологічної цінності. 
Цілі статті. Метою роботи $є$ дослідження засвоюваності білків продуктів для ентерального харчування системою ферментів шлунковокишкового тракту для визначення їх біологічної повноцінності.

Об'єкт дослідження. Об'єктом дослідження є розроблені продукти для ентерального харчування серії "Vitalprod", призначені для хворих 3 певними захворюваннями, зокрема:

- продукти для ентерального харчування хворих в критичних станах "Vitalprod-Combi";

- продукти для ентерального харчування людей 3 порушеною толерантністю до глюкози "Vitalprod-Diabet";

- продукти для ентерального харчування хворих 3 онкологічними захворюваннями "Vitalprod-Forte";

- продукти для ентерального харчування хворих 3 нирковою недостатністю "Vitalprod-Renal".

Продукти представлено у різних товарних формах, зокрема - сухих сумішей, рідкій готовій до вживання формі, драглеподібній, сухих сумішей для виготовлення пудингів, готових пудингів.

В якості контрольних зразків обрано:

- д для сухих розчинних продуктів - продукт "Resourse Optimum" виробництва компанії "Nestle" (Швейцарія) - контроль 1; продукт "Реабілакт" вітчизняного виробництва - ТОВ “ДелМас” - контроль 2;

- $\quad$ для драглеподібних продуктів -продукт “Гематоген”, виробництва ПП “Осіріс”, Україна м. Дніпропетровськ;

- $\quad$ для сухих сумішей для виготовлення пудингу - продукт "Пудинг 3 ванільним смаком” виробництва ТОВ “Др. Оеткер”, Румунія.

Методи дослідження. У розроблених продуктах для ентерального харчування досліджено атакуємість білків in vitro комплексом протеолітичних ферментів - пепсином та трипсином. Дослідження проводили згідно вимог ДСТУ 7617:2014 "Продукти харчові. Метод визначення засвоюваності білка" та методики Покровського-Сртанова $[6,8]$.

Виклад основного матеріалу дослідження 3 повним обгрунтуванням отриманих наукових результатів. Встановлено, що перетравлюваність білків сухих розчинних продуктів для ентерального харчування знаходиться в на рівні $59 . .72 \%$ (рис. 1).

Найвищий ступінь перетравлюваності білка мають продукти "VilalprodCombi” та контрольний зразок 1. 
Товарознавчий вісник. - 2018. - Випуск 11.

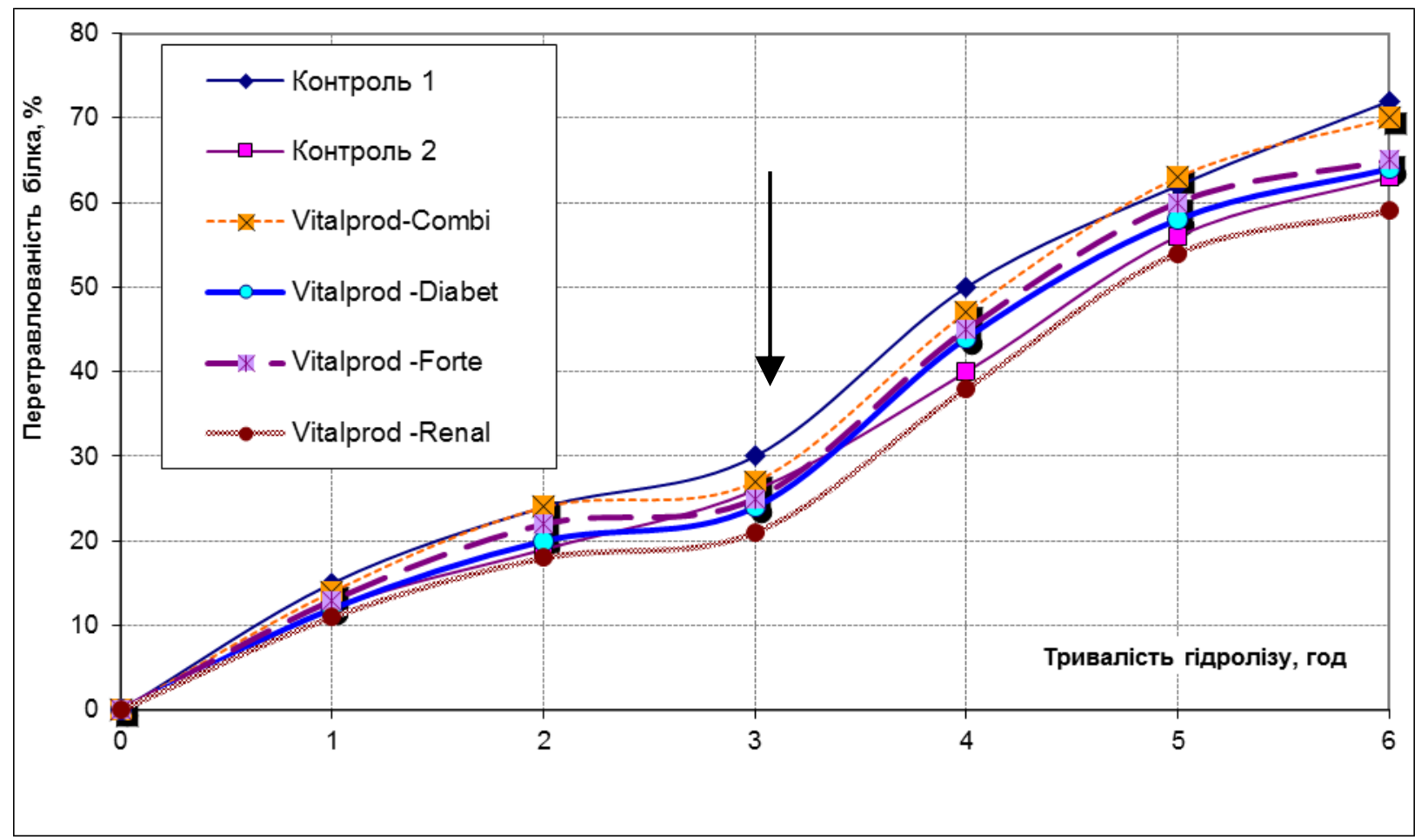

\section{Рис. 1. Перетравлюваність білків сухих розчинних продуктів для ентерального харчування системою ферментів пепсин-трипсин}

Примітка. Стрілка показує момент введення трипсину

Це пов'язано з переважанням у їх складі концентрату молочного білка, що має високий показник перетравлюваності. Продукт "Vilalprod-Renal" має найнижче у порівнянні 3 іншими продуктами значення показника перетравлюваності (59\%), що, очевидно, пов'язано з наявністю у складі продукту соєвого ізоляту, що має невисокий ступінь перетравлюваності. Одержані результати корелюють з літературними даними. У готових до споживання продуктів для ентерального харчування значення показника перетравлюваності білків знаходиться у межах $63 . .74$ \%, що є дещо більшим у порівнянні з сухими продуктами за рахунок набухання білків в результаті процесу відновлення.

Драглеподібні продукти для ентерального харчування мають досить високий показник перетравлюваність білків - 64...76 \%, що наближається до значень, встановлених у готових до споживання продуктах. Враховуючи незначний вміст білка у контрольному зразку даних щодо нього не наведено. Аналіз даних рис. 2 свідчить, що білки досліджуваних продуктів характеризуються високим ступенем гідролізованості як пепсином, так i трипсином. 
Товарознавчий вісник. - 2018. - Випуск 11.

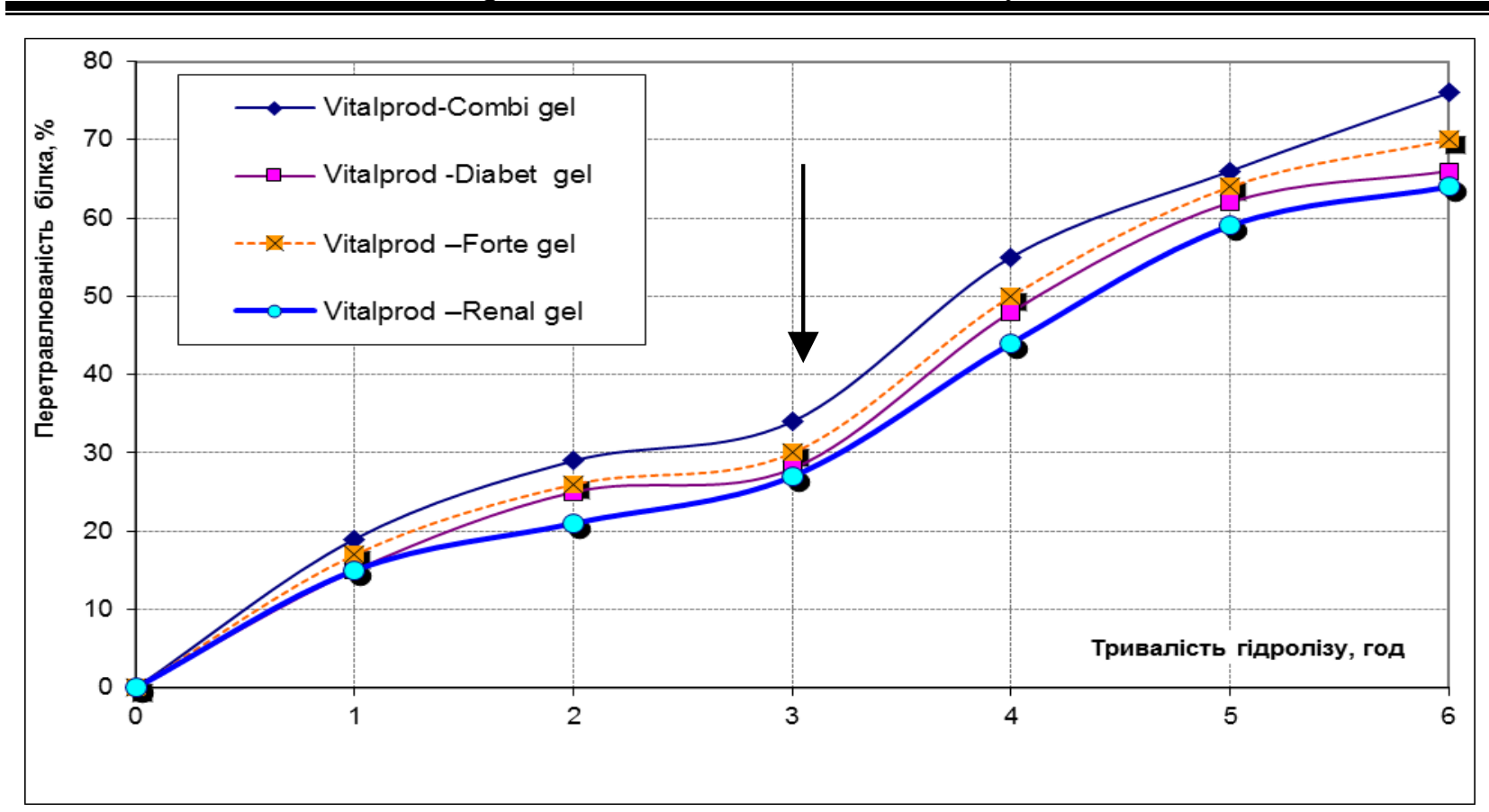

Рис. 2. Перетравлюваність білків драглеподібних продуктів для ентерального харчування системою ферментів пепсин-трипсин

Примітка. Стрілка показує момент введення трипсину

У сухих сумішах для виготовлення пудингу показник перетравлюваності складає $65 . .56 \%$, зокрема, найбільше значення показника встановлено у продукті "Vilalprod-Combi”, найменше - у продукті "Vilalprod-Diabet", дещо нижчий ступінь гідролізованості пепсином і трипсином продукту пов'язано 3 наявністю екстракту гарбуза, в складі якого $є$ досить висока кількість інгібіторів трипсину.

У готових пудингах для ентерального харчування встановлено вищу ступінь розщеплення білків у порівнянні з сухими сумішами - $65 . .73 \%$ (рис. 3). Це зумовлено протіканням процесу відновлення, під час якого відбувається набухання білків та відновлення їх фізико-хімічних властивостей. Пудинг при виготовленні проходить додаткову термічну обробку, що також сприяє підвищенню перетравлюваності продуктів [3].

Таким чином, одержані дані свідчать про те, що продукти для ентерального харчування легко піддаються гідролізу. Встановлено, що у всіх досліджуваних продуктах залежності мають подібну тенденцію - процес як в пепсиновій, так і в трипсиновій стадіях найбільш стрімко проходить за першу годину та за цей час утворюється найбільша концентрація продуктів розщеплення. Після сповільнення протягом другої години процесу гідроліз пепсинової стадії знову прискорюється на третій годині. Це пояснюється 
Товарознавчий вісник. - 2018. - Випуск 11.

наявністю у досліджуваних продуктах рослинних екстрактів, які переважно характеризуються повільним протіканням гідролізу.

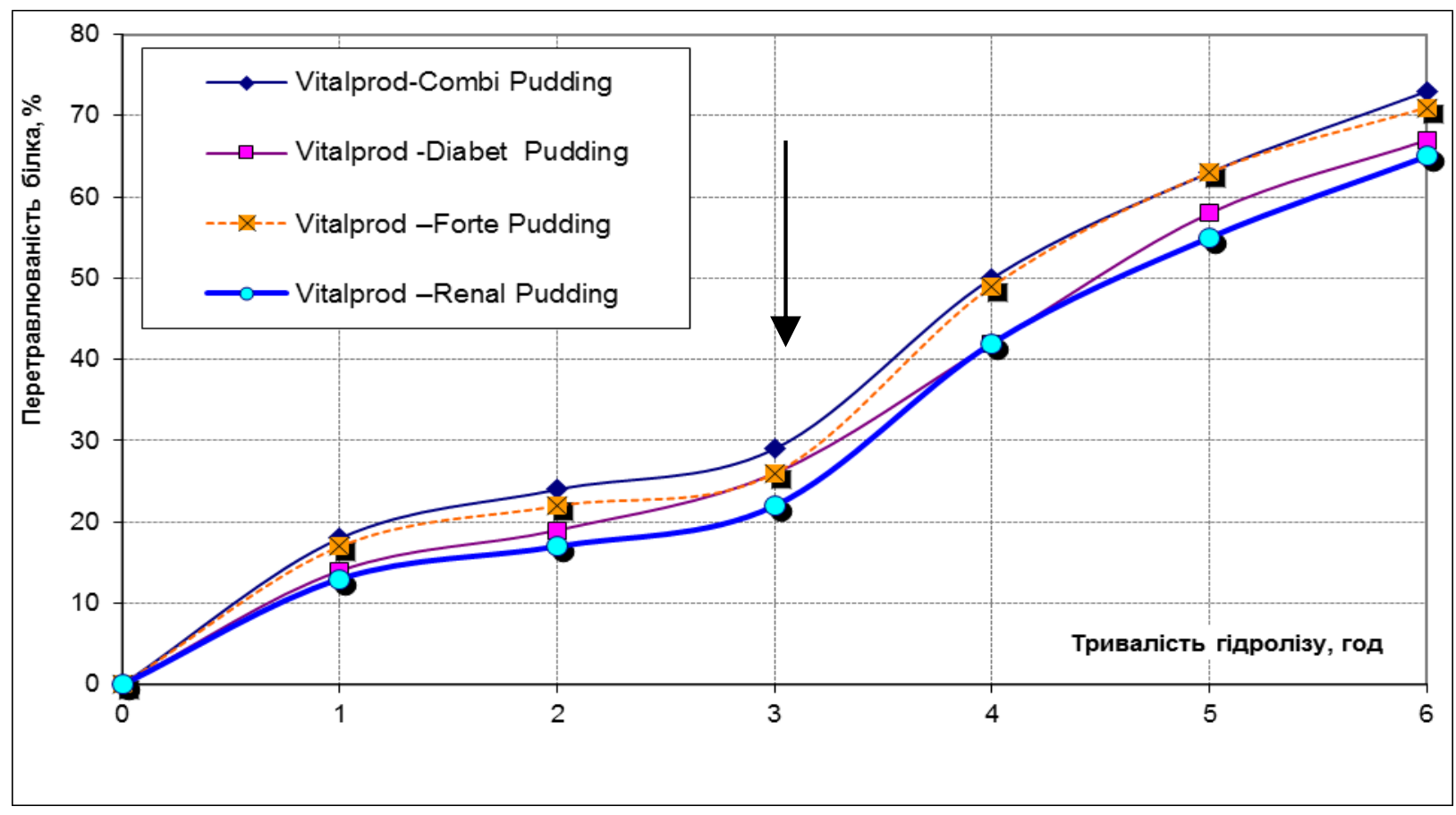

Рис. 3. Перетравлюваність білків готових пудингів для ентерального харчування системою ферментів пепсин-трипсин

Примітка. Стрілка показує момент введення трипсину

Згідно класифікації Покровського А.А. продукти можна віднести до 1 групи харчових продуктів, яким притаманний швидкий темп перетравлюваності білка [4].

При зберіганні продуктів для ентерального харчування амінокислоти можуть вступати в перехресні реакції 3 іншими компонентами продуктів [3,5]. Внаслідок даного процесу відбувається «блокування» незамінних амінокислот, особливо лізину, метіоніну та цистину. Це може спричинити зниження засвоєння білка організмом людини. Дослідження атакуємості білків виробів in vitro протягом передбачуваного терміну зберігання засвідчили, що перетравлюваність білків у зразках знизилась на 1,8-3,5 \%. Зміна цієї характеристики проходить за рахунок зменшення доступного лізину у продуктах. Отримані результати підтверджуються експериментальними даними інших дослідників [3,4].

Висновки та перспективи подальших досліджень. Білки продуктів $\epsilon$ повноцінними, достатньо збалансованими, що свідчить про їх високу біологічну цінність. Використання у складі продуктів концентрату з молочної 
сироватки та відповідна підготовка продуктів до споживання підвищують доступність білка для протеолітичних ферментів. Це дозволяє рекомендувати включення продуктів у харчування хворих та травмованих осіб. Таким чином, показник перетравлюваності білків розроблених продуктах для ентерального харчування дає підстави визначати їх як продукти 3 високим рівнем біологічної цінності. Доцільним у подальшому є проведення досліджень 3 підтвердження фізіологічної ефективності розроблених продуктів для ентерального харчування.

\section{Література}

1. Попова Т.С. Парентеральное и энтеральное питание в хирургии. - Москва : Медицина, 1996. - 198 с.

2. Рогов И. А. Химия пищи / И. А. Рогов, Л. В. Антипова, Н. И. Дунченко - М.: Колос С, 2007. - 853 с.

3. Горбатова К.К. Биохимия молока и молочных продуктов. - С.-Пб.: ГИОРД, 2001. - 320c.

4. Покровский, А.А. О биологической и пищевой ценности продуктов питания [Текст] / Покровский А.А. //Вопросы питания. -1975. - № 3. - С. 25-29.

5. Липатов Н.Н. Усовершенствованный прибор и методика для определения переваримости белков in vitro [Текст] / Липатов Н.Н., Юдина С.Б., Лисицин А.Б. // Вопросы питания. - 1994. - № 4 - С. 43-44.

6. Чернова Е.В. Новый метод оценки биологической ценности белков кулинарно обработанных круп [Текст] / Чернова Е.В. //Известия вузов. Пищевая технология. - 2001. - № 1 - С. 11-13.

7. Рудакова Т.В., Наріжний С.А., Ферментативний метод визначення біологічної цінності молочних продуктів із зерновим інгредієнтом для дитячого харчування //Зернові продукти і комбікорми. - 2017. - Vol.17, I. 2. - C. 25-27.

8. ДСТУ 7617:2014. Продукти харчові. Метод визначення засвоюваності білка. [Чинний від 2015-07-01]. - К.: Мінекономрозвитку України, 2015. - 8 с.

Цель. Исследование усвояемости белков продуктов для энтерального питания системой ферментов желудочно-кишечного тракта для определения их биологической полноченности.

Методика. Исследования проводились в соответствии с требованиями ДСТУ 7617:2014 "Продукты пищевые. Метод определения усвояемости белка "и методики Покровского-Ертанова. Суть метода заключается в исследовании атакуемости белков іп vitro комплексом протеолитических ферментов - пепсином и трипсином.

Результаты. Установлено, что продукты для энтерального питания легко подвергаются гидролизу. Во всех исследуемых продуктах зависимости имеют подобную тендениию - процесс как в пепсиновой, так и в трипсиновий стадиях наиболее стремительно проходит за первый час и за это время образуется наибольшая концентрация продуктов расщепления. После замедления в течение двух часов процесса гидролиз пепсиновой стадии снова ускоряется. Это объясняется наличием в исследуемых продуктах растительных экстрактов, которые преимущественно характеризуются медленным прочессом гидролиза. Согласно классификачии Покровского А.А. продукты можно отнести к 1 группе пищевых продуктов, которым присущ быстрый темп переваримости белка. При хранении продуктов для энтерального питания аминокислоть 
могут вступать в перекрестные реакции с другими компонентами продуктов. Вследствие данного проиесса происходит «блокировки» незаменимых аминокислот, особенно лизина, метионина и ичистина. Это может привести к снижению усвоения белка организмом человека. Исследование атакуемости белков продуктов in vitro в течении предполагаемого срока хранения показали, что перевариваемость белков в образиах снизилась на 1,8-3,5\%. Изменение этой характеристики происходит за счет уменьшения доступного лизина в продуктах.

Научная новизна. Установлень закономерности усвояемости белков продуктов для энтерального питания системой ферментов желудочно-кишечного тракта в процессе их хранения.

Практическая значимость. Проведенные исследования по переваримости белков подтвердили высокую биологическую иенность продуктов для энтерального питания. Это позволяет рекомендовать включение продуктов в питание больных и травмированных лич.

Ключевые слова: усвояемость, биологическая ченность, фермент, качество, перевариваемость, продукт для энтерального питания, хранение.

Purpose. The study of assimilability of proteins of products for enteral nutrition by the enzyme system of the gastrointestinal tract to determine their biological usefulness.

Methodology. The studies were conducted in accordance with the requirements of DSTU 7617: 2014 "Food Products - Method for Determining the Assimilability of Protein" and Pokrovsky-Ertanov's methods. The essence of the method consists in the study of the in vitro attack of proteins by a complex of proteolytic enzymes - pepsin and trypsin.

Findings. It has been established that the products for enteral nutrition are easily hydrolyzed. In all studied products, the dependencies have a similar tendency - the process in both the pepsinic and trypsinium stages is most rapid in the first hour and during this time the greatest concentration of the cleavage products is formed. After a deceleration within two hours of the process, the hydrolysis of the pepsin stage is again accelerated. This is due to the presence of plant extracts in the products, which are mainly characterized by a slow hydrolysis process. According to the classification of AA Pokrovsky. products can be attributed to the 1 group of food products, which are inherent in the rapid rate of protein assimilability. When storing products for enteral nutrition, amino acids can cross-react with other components of the products. As a result of this process, there is a "blocking" of essential amino acids, especially lysine, methionine and cystine. This can lead to a decrease in the absorption of protein by the human body. Investigation of the inactivity of protein products in vitro during the intended shelf life showed that the digestibility of proteins in the samples decreased by 1.8-3.5\%. Change of this characteristic occurs due to reduction of available lysine in products.

Originality. The patterns of assimilability of food proteins for enteral nutrition by a system of enzymes of the gastrointestinal tract during their storage are established.

The practical value. The conducted studies on the assimilability of proteins confirmed the high biological value of products for enteral nutrition. This allows us to recommend the inclusion of foods in the diet of patients and injured persons.

Keywords: assimilability, biological value, enzyme, quality, digestibility, enteral nutrition product, storage.

Рекомендовано до публікачії докт. техн. наук, професором, завідувачем кафедри товарознавства, управління безпечністю та якістю Київського національного торговельно-економічного університету Белінською С.О. Стаття надійшла в редакиію 31.01.2018 p. 